\title{
Allison Stielau
}

University College London

\section{Kwab: Dutch Design} in the Age of Rembrandt

Rijksmuseum, Amsterdam

June 30-September 16, 2018

Catalogue

Kwab: Ornament as Art in the Age of Rembrandt

Reinier Baarsen; with a contribution by Ine Castelijns van Beek

Amsterdam: Rijksmuseum, 2018.

284 pp., 335 ills.

Hardback $€ 40$

Available in Dutch and English

ISBN 9789462084278 (Dutch)

ISBN 9789462084285 (English) 
Among the acknowledged treasures of the Rijksmuseum, one of a few select masterpieces to remain on view during a decade-long renovation is a ewer made in 1614 by the Utrecht silversmith Adam van Vianen (fig. 1). A few forms are recognizable in its surface-the monkey-like creature bearing the volume of the cup on its shoulders, a nude woman's back curved over where the handle is meant to be-but these morph into indistinct areas without ready description, a roiling mass of slick, wormy, shuddering stuff. That stuff, as a recent exhibition grounded in Van Vianen's ewer taught us, is kwab, the "flabby fold or thickening ... of a human or animal body" that featured prominently in an ornamental mode that became popular in the seventeenth-century Dutch Republic. Kwab: Dutch Design in the Age of Rembrandt introduced audiences to this ornamental mode, locating its innovation in the work of two talented families of silversmiths and tracking its gradual spread both geographically, within and beyond the Dutch Republic, and medially, from precious metals into wood, brass, leather, ivory, and even baleen.

Curated by Reinier Baarsen, with an accompanying catalogue in Dutch and English editions, the exhibition attempted to apply the same attention to this often-overlooked style that major exhibitions gave to the rococo and baroque a decade ago. ${ }^{1}$ The focus here, however, was temporally and spatially narrower. Reflecting the curator's stated desire to fill "the lack of a comprehensive study of kwab" (7), the exhibition seemed to be reestablishing originating contexts as preparation for future investigation. The catalogue consolidates current research on kwab, which is known in English as the auricular style, to a tight, well-argued narrative that dispenses with long-held assumptions while pointing to new avenues of research. It thus reads like a very thorough and spectacularly illustrated state-of-the-field essay, one that will quickly become the new foundation for any subsequent discussion of kwab.

Spread over ten rooms in the Rijksmuseum's Philips Wing, the show gave ample space to precious metalwork and other decorative arts that museums often crowd into tight quarters. The breathing room surrounding individual vitrines signaled a measure of respect for works whose contemporary significance can often be overlooked when the audience's focus, especially in the Rijksmuseum, is so intensely trained on painters of the Dutch Golden Age. When it came to kwab, however, it was goldsmiths who fueled the creative engine, producing forms that inspired painters to imitation and invention. Rembrandt's inclusion in the show's title is not merely an enticement to draw visitors from the Gallery of Honour, 


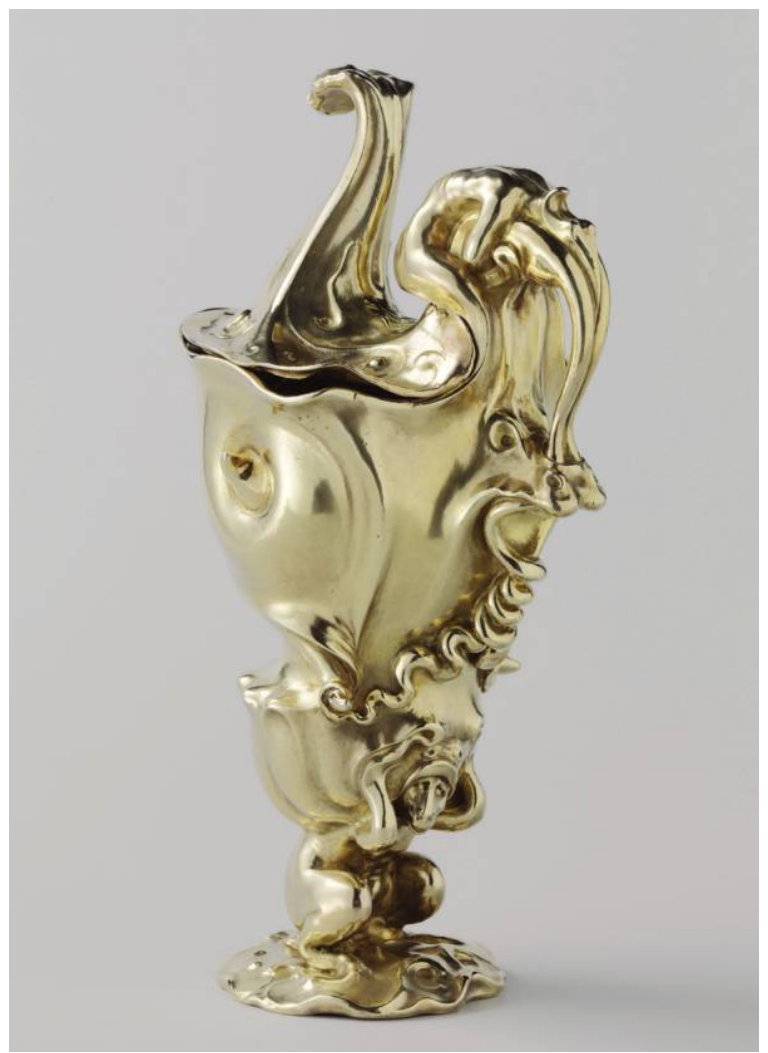

Fig. 1 Adam van Vianen, ewer, Utrecht, 1614. Silver-gilt; $9 \frac{7 / 8}{8} \times 5 \frac{1}{2} \times 3 \frac{5}{8}$ in. $(25 \times 14 \times 9 \mathrm{~cm})$. Amsterdam, Rijksmuseum, inv. no. BK-1976-75.

where his Night Watch has pride of place. In fact, the painter was evidently fascinated by kwab, which, upon his arrival in Amsterdam, graced only precious metalwork. In painted portraits and history paintings, Rembrandt inserted auricular furniture, frames, and even wall coverings of his own invention, pushing the fantastic style beyond the limits of the practical requirements of real chairs and beds. ${ }^{2}$ These fictive pieces achieved a more extended life in paint when they were copied by Rembrandt's followers; they also seem to have "stimulated the emergence of carved auricular furniture" for elite Dutch interiors (114). 
The inventors and propagators of kwab, Baarsen argues, represented the final stage in the prominence of the goldsmith in European artistic life. Born and trained in Utrecht, Paulus van Vianen (ca. 1570-1613) traveled the continent in the late sixteenth century, developing his technique and stylistic repertoire in commissions for elite patrons. In 1603 he was appointed court goldsmith to the Holy Roman emperor, Rudolph II, in Prague, where he joined a fertile milieu of experimentation in alchemy and the arts and gained access to collections including recent pieces by tremendously gifted and risk-taking goldsmiths. Van Vianen was a skilled draughtsman whose plein air drawings stand on their own in the early history of European landscape. They resurfaced in the subtle reliefs in silver he produced for Rudolph, usually of mythological subjects. On precious metal vessels, Van Vianen began to frame such scenes with ornament drawn from grotesque traditions like strapwork and printed designs for vessels made from animals and body parts. But Van Vianen departed from the legible composite, causing faces and anatomies to stretch and merge: the origin of the ornament now called kwab.

Adam van Vianen (1568/69-1627) remained in Utrecht but kept tabs on his successful brother's inventions. When Paulus died in 1613, Adam was asked by Amsterdam's silversmith guild to produce a piece in his memory. As Baarsen notes, this was a supremely unusual request- the Van Vianens were from Utrecht, after all, and Paulus had been working even farther afield. It reflected Paulus's fame as an artist and the clamor of another Dutch city's smiths to claim him as their own. Adam's memorial to his brother is taxonomically still a ewer, with the recognizable features of handle, lid, spout, and interior. But it is really a dynamic sculpture that takes the uncanny energy working through his brother's auricular frames and applies it in three dimensions. No other auricular piece would ever achieve this daring level of molten movement and ambiguity of form. Its singularity was immediately recognized by artists across all media, who copied it in two and three dimensions, eventually even setting it into genre and history paintings.

The ewer's renown in the history of kwab, as well as seventeenth-century Dutch art more generally, is belied by its height of just ten inches. A hypnotizing film by Robert Erdmann in the exhibition's introductory gallery blows the ewer up to taller-than-human scale. The film illustrates, we are told, "the sensation of handling" the piece, which remains inaccessible to the visitor's grasp in the exhibition's third gallery. Making the ewer's details larger than life with hyper-close-ups that become panning shots over its surface and interior, the film then shows the 
vessel rotating independently in white space, in triplicate views that grant simultaneity to all sides. It is too simple to say that here the experience of handling the object is approximated, however, because the film captures the ewer beyond how it can be observed in physical reality. This is just the latest in a long tradition of portrayals of the ewer, all of which interpret and transform their subject. The particular affordances of film place the emphasis here on the temporality and what Baarsen aptly calls the mouvementé of the most dazzling auricular surfaces.

One of the fascinating challenges of kwab is its enduring resistance to definitive description. Seventeenth-century writers-whether art theorists, inventory recorders, or artist biographers-offered very little verbal traction on these works, employing the term snakerijen (defined by Baarsen as "coarse jokes or rustic pranks") or categorizing them in the general realm of caprices or grotesques. Kwab, the wonderfully evocative German Ohrmuschelstil (earlobe style), and the English lobate or auricular, are all modern terms. The lack of contemporary written discussion combined with modern frustration at description has often scuttled interpretation of the style beyond connoisseurship. The language used to wrestle with auricular ornament suggests the push-pull into and out of recognition and the sayable. Single adjectives and nouns do not suffice, so they appear in lists: "soft, treacly or slimy" (11); "waves, membranes, bones, wings, spines and equivocal openings" (78). Kwab must be sidled up to, approached by means of analogy; if it does not exactly represent bone, it represents something like bone. This game of articulation was surely an aspect of the conversations that took place around, and which are consistently invoked to explain the early modern reception of, mannerist vessels. Baarsen contributes to this ekphrastic tradition, finding inventive ways to describe the strangeness of individual works. Most innovatively, he moves beyond the problem of finding adequate descriptors by simply treating kwab as a recognizable, unique material subject to its own rules.

In the thirteen years following the triumph of his ewer, Adam van Vianen continued to work in Utrecht, producing pieces whose kwab elements moved increasingly toward naturalism. The exhibition included a number of drawings now attributed to Van Vianen and related smiths, a crucial element of design and execution that, due to current location and conservation issues, rarely get to accompany surviving metalwork on display. After Adam's death in 1627, his son Christiaen (ca. 1600-1667) took over the workshop and the mantle of the auricular, eventually moving to England, where he produced magnificent silver plate for Charles I and private clients alike. Christiaen also set about 


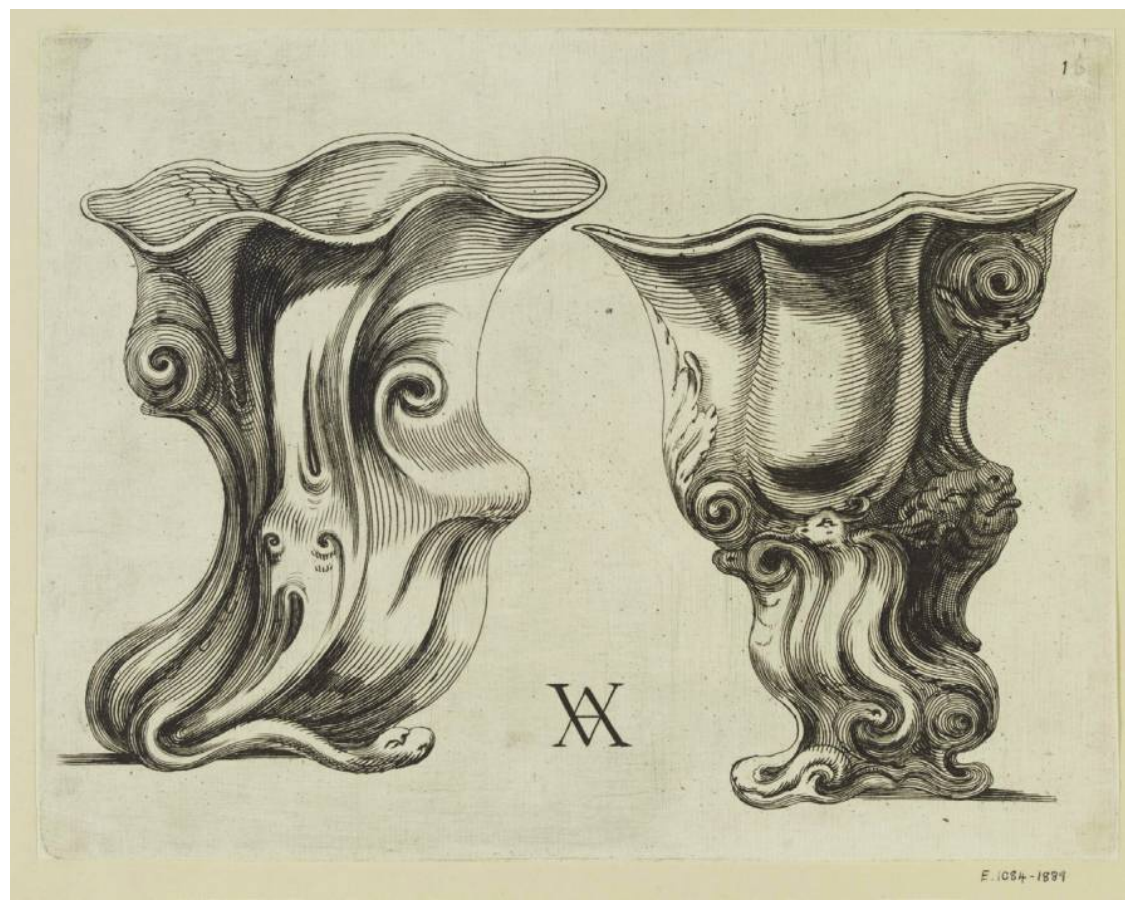

Fig. 2 Theodorus van Kessel after Adam or Christiaen van Vianen, "Two Cups," no. 16, from Constighe Modellen, Utrecht, ca. 1646-52. Etching; $61 \frac{1}{2} \times 8 \frac{3}{8} \mathrm{in}$. $(16.4 \times 21.2 \mathrm{~cm})$. London, Victoria and Albert Museum, inv. no. E. 1084-1889.

consolidating his family's reputation for inventive metalwork by publishing etchings of Adam's designs beginning in 1646 (fig. 2). The series known as Constighe Modellen (Artful models) by Theodorus van Kessel was geared toward an international audience of connoisseurs, with title pages styled in Italian, French, and Dutch. The forms captured in Van Kessel's etchings were conceived not as ornament but as clever inventions, even art. 
On the heels of Van Kessel's etchings came several series of prints intended, Baarsen asserts, to solidify the claims of another goldsmith to the status of designer and innovator. The Amsterdam smith Johannes Lutma (1584-1669) designed wide-lipped, monstrous cartouches in the auricular mode for funeral shields and other metalwork. Published by his son Jacob in the early 1650 s, these framing devices proved applicable across a wide variety of media (fig. 3). In terms of size, prestige, and visibility to the widest cross section of Amsterdam society, Lutma's most significant commission was the design of the brass choir screen in the Nieuwe Kerk around 1654. The exhibition displayed a door from this piece in a section on brass church fittings, which was the category of functional object that sustained auricular ornament the longest. Responding to the existing late medieval tradition of brass choir screens set into wooden frames, Lutma transformed Gothic tracery into an auricular membrane of spiny arches opening into mask-shaped holes. Such auricular designs in brass may even have reached Japan as diplomatic gifts through governors of the Dutch East India Company: a standing chandelier of about 1640 now in Nikko bears auricular flourishes and the same twisting columns from Lutma's screen (143).

Lutma was portrayed by Rembrandt in an etched portrait of 1656, the older bearded man seated and resting an elbow near the punches and hammer of his trade and one of his silver vessels, also in the exhibition (fig. 4). This whirling bowl of metal appears to be an even more amorphous version of the goldsmith's earlier cartouches, with forms that are ever in transition: a yawning maw, a skull, but somehow also a puddle into which a snail-like glob attempts to dip its hideous head. Portraiture provides a subtle but intriguing theme to this show as the means by which star smiths linked the person of the artist-inventor with his unique designs in kwab, not just signaling elevated status but also a solidifying artistic legacy. The step of portraying a goldsmith with one of his own unique pieces-as opposed to the more generic items seen in some late medieval portraits-probably responded to the notoriety of the Van Vianens, whose fame was by now inextricably linked to Adam's singular ewer.

Running parallel to the drama of the Van Vianens' and Lutmas' achievements is the dissemination of the auricular mode, which was plotted geographically in the exhibition and accompanying catalogue. Beginning with Paulus's work in Prague, the narrative shifts to Adam's Utrecht and the Lutmas' Amsterdam, then to other Dutch cities where goldsmiths had been inspired by auricular 


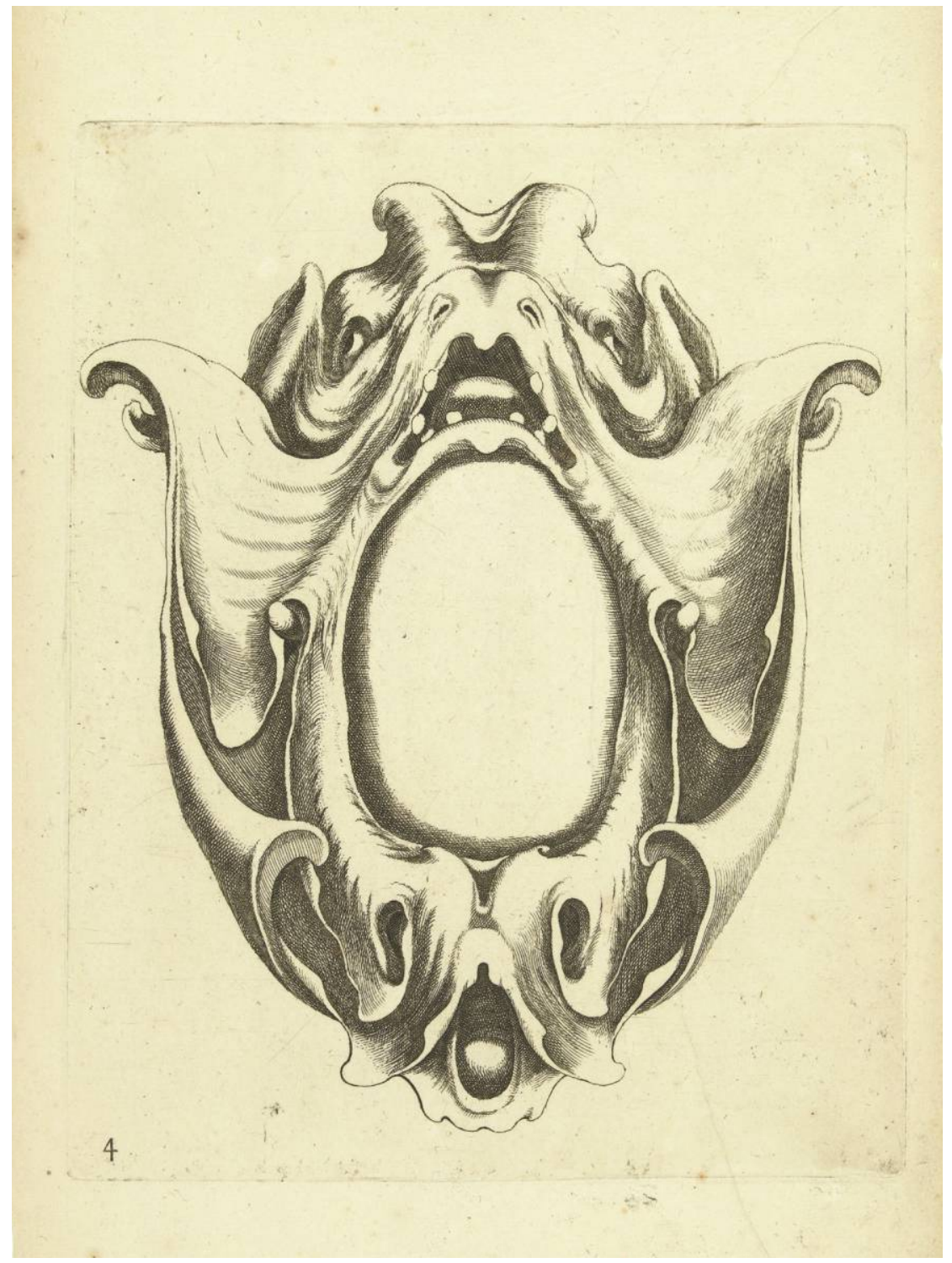

Fig. 3 Jacob Lutma after Johannes Lutma, cartouche with mask with gaping mouth, from the series Veelderhande nieuwe Compartemente, ca. 1654-ca. 1678. Etching; $9 \times 7 \frac{1}{4}$ in. $(22.7 \times 18.3 \mathrm{~cm})$.

Amsterdam, Rijksmuseum, inv. no. RP-P-1885-A-9219. 


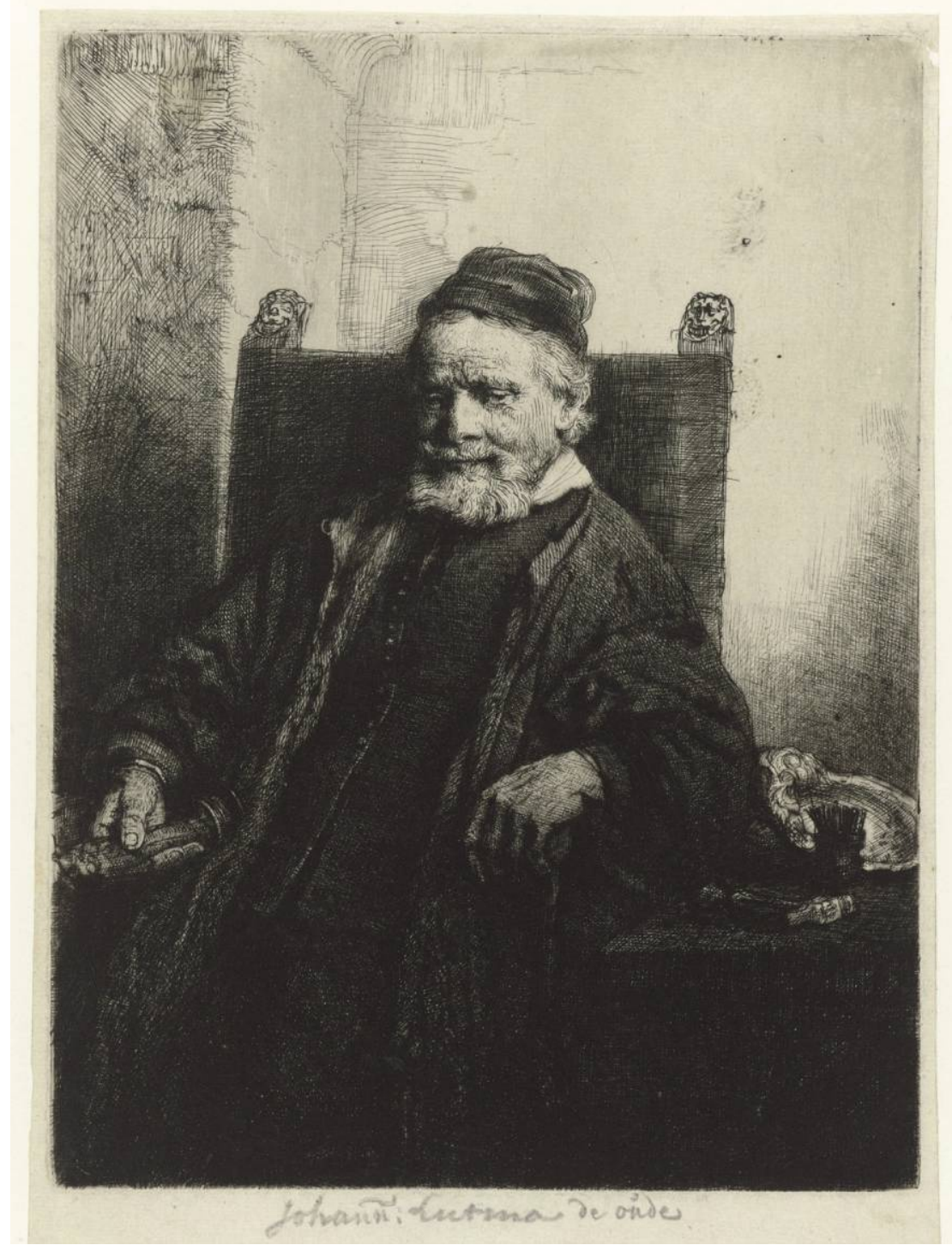

Fig. 4 Rembrandt van Rijn, Portrait of Johannes Lutma (first state), 1656. Etching, engraving, and drypoint; $7 \frac{7}{8} \times 5 \frac{7}{8}$ in. $(19.8 \times 14.8 \mathrm{~cm})$. Amsterdam, Rijksmuseum, inv. no. RP-P-OB-550. 
inventions. From precious metalwork, the auricular was taken up into other media, including carved wooden frames and furniture, brass fittings, and, most colorfully, raised leather wall coverings that transformed large surface areas into shimmering auricular skins. Sometimes visible glinting in the backgrounds of Dutch domestic scenes, gilt wall coverings were a luxury export commodity that imitated metalwork - they were made by pressing leather into molds-and goldsmiths, including those working in auricular motifs, often had a hand in designing them. Surviving examples are rare, but the exhibition brought together a few magnificent ones, which indicate how auricular ornament looked beyond the monochromes of gold, silver, and highly polished wood (fig. 5). Gilt leather samples from Skokloster Castle in Sweden show a riot of jewel-toned auricular, vegetal, and marine motifs tumbled together. The background of one surviving piece is set with splintered glass that sparkles marvelously behind painted oranges and silvery forms undulating like skates.

The exhibition's penultimate gallery was devoted to England-specifically, the auricular picture frames produced there and a few of Christiaen van Vianen's surviving silver vessels, like the so-called Dolphin Basin of 1635, which frames a watery pool with the rippling bodies of sea creatures. ${ }^{3}$ This room appeared at first glance to be the show's conclusion, located at its exit, but a side gallery to the right opened onto the final turn: the spread of auricular ornament in Europe. Particularly exciting here were the carved wooden frames and furniture of Hans Gudewerth the Younger, in the unusual northern German mode of Knorpelwerk, the knottier and more angular descendant of kwab, which was disseminated through design prints by Nikolaus Rosman. In precious metal, too, German artisans were fascinated by this style, as is clear from the gilt silver basin by the Augsburg smith Abraham Warnberger II, with its wide frame of marine surfaces reminiscent of sea urchins and horseshoe crabs. In other examples, the auricular had become almost camouflaged in the tiny framing elements and inlay of luxury cabinets.

The show's exclusive emphasis on superelite objects meant that the eventual spread of auricular ornament was never fully explored. In fact, the fleshy curls of auricular cartouches became fairly commonplace in seventeenth-century Europe, in architectural ornament (some of it visible on the exterior of the Rijksmuseum), shop signs, and myriad framing devices in coins, medals, and print culture, including the cartouches surrounding the legends on maps. 


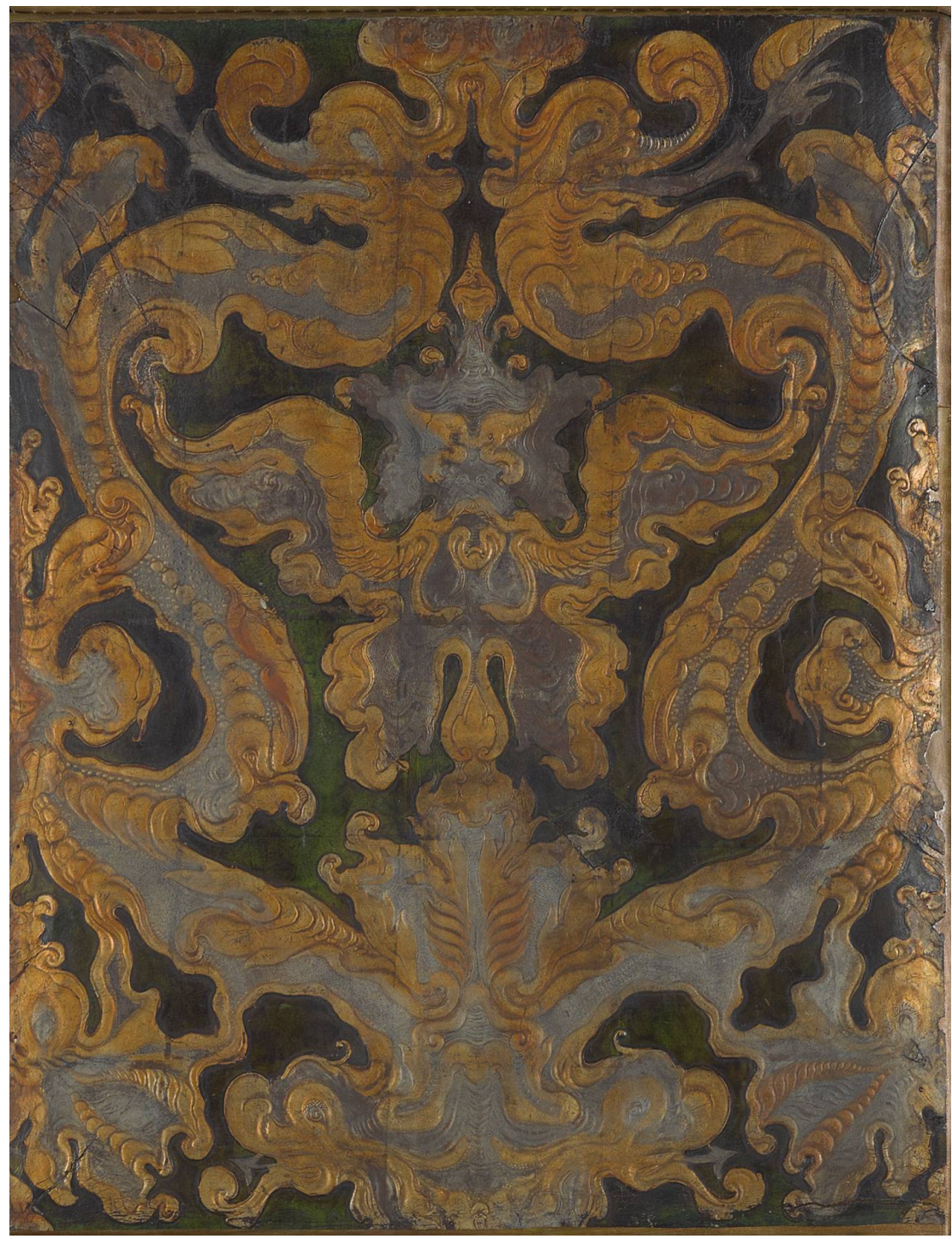

Fig. 5 Company for Making Gilt Leather, gilt leather hanging with auricular motifs, The Hague, ca. 1649. Leiden, Museum De Lakenhal, inv. no. 183.1.A. 
Previous overviews of auricular ornament in the scholarly literature on early modern European design movements have traced its earliest origins in Dutch silver to the point of its broadest dissemination, even deracination, in almost generic ornament. ${ }^{4}$ The Rijksmuseum exhibition concluded not with this proliferation and the inevitably wider audience it reached but rather on a few outstanding pieces of German and French cabinetry whose precise significance to the legacy of kwab remains unclear. Perhaps the echoey emptiness of the final gallery is a further indication of the exhibition's prospective stance and the opening of paths forward to future research.

Baarsen, the Rijksmuseum's senior curator of furniture and a former curator of gold and silver, has published extensively, including major catalogues of Dutch furniture and French decorative arts. His particular interest in opulent largescale storage pieces is clearly apparent in the elaborate cabinets chosen to convey the auricular style's movement from precious metal to other media, such as Herman Doomer's cabinet (National Trust, Dungannon, The Argory) veneered with ebony and inlaid with mother-of-pearl tulips, lilies, and banderoles, whose precise auricular details glitter like cut jet. Rather than a series of thematically organized entries on individual works, the catalogue presents a set of chapters that correspond to the general themes of the exhibition; entries consisting of updated tombstone information, provenance, and literature form a section at the end contributed by Ine Castelijns van Beek. The need for its art historical narrative to fit the general thematic structure of the exhibition means the text, which is written in an engaging and readable style, can at times be slightly repetitive. It ends, perhaps appropriately, without a summarizing conclusion.

Surprisingly absent from the exhibition were relevant and significant works from the Rijksmuseum's own collection, including pieces by the Van Vianens, and still lifes depicting auricular vessels. It may be that readjusting such a heavily visited and carefully installed permanent collection made their inclusion prohibitive. Still, it was a pity to see the Kwab exhibition so sparsely attended when on the other side of the building, visitors were fighting for glimpses of the paintings in the Gallery of Honour. Perhaps it is to be expected that a show about design and ornament, and an obscure mode of ornament at that, would not attract the same visitors as Vermeers and Rembrandts. But visitors were not particularly encouraged toward the Philips Wing. The massive poster advertising the show in the museum's atrium omitted the exhibition's subtitle, which hypes the Rembrandt connection. And significant 


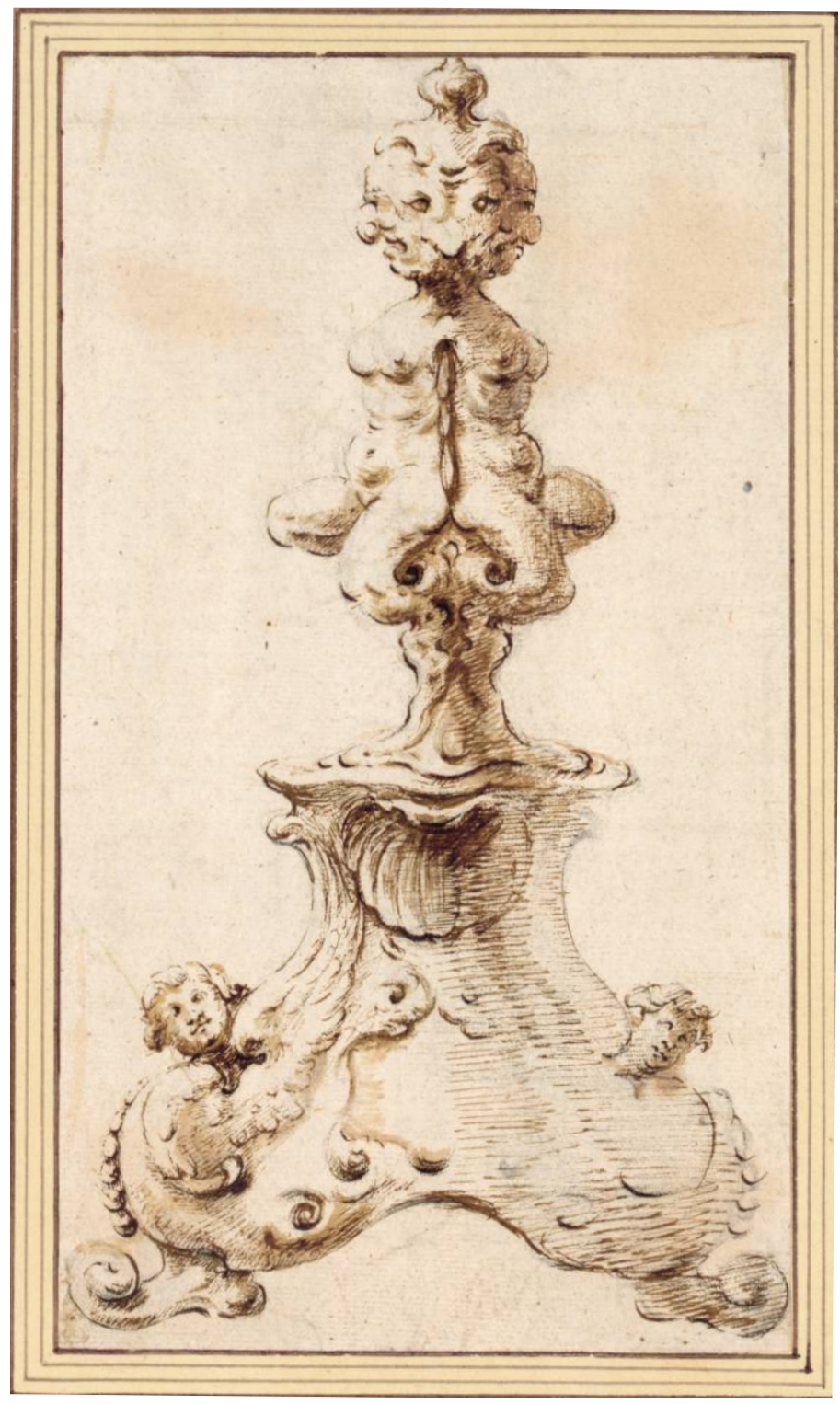

Fig. 6 Attributed to Adam van Vianen, Design for a Saltcellar (?), Utrecht, ca. 1610-27. Pen and brush and brown ink over black chalk; $8 \frac{7}{8} \times 5 \frac{1}{8}$ in. $(22.6 \times 12.8 \mathrm{~cm})$. Vienna, The Albertina Museum, inv. no. 8721 . 
works with auricular ornament by the star silversmiths of the exhibition, on display in the permanent collection galleries, were not connected by signage to the special exhibition.

The postmodern bombast of Keso Dekker's exhibition design at times threatened to overpower the seventeenth-century works it framed. Clearly an attempt to manage the massive and high-ceilinged galleries now devoted to a number of fairly small objects, the wall and floor coverings made themselves aggressively visible. Adam van Vianen's ewer stood on a pedestal in a vitrine placed within a circle of radiating white stripes, as if this tiny masterpiece needed-after its introduction by monumental film - a graphic force field to call our attention to it. Punctuated throughout the galleries by white ellipses, circles, and stripes, the black floor not only played on the ebony-and-ivory veneers of some of the exhibition's stunning cabinets; it also recalled the checkered marble flooring of some seventeenth-century interiors. ${ }^{5}$ Despite these historical references, every squeak of my shoe across the floor's rubberized surface jerked me back like a record scratch to the reality of 2018 , whose materials seemed instantly impoverished in comparison to those on display.

The envelope-pushing demonstrated in the exhibition's design did not extend to innovations in the display of silver objects, with the notable exception of the opening film, which along with the excellent catalogue photography used advanced imaging techniques to portray the objects in ways that cannot be duplicated in a gallery. Individual pieces were contained in spotlit glass cases that created such deep shadows I was forced on occasion to use my smartphone's flashlight to see the details pointed out by wall labels, particularly on elements such as stems and feet. Basins were displayed either horizontally or vertically, making one wonder whether other angles might have been explored to work within the specific lighting conditions of the space, or whether the oft-invoked effects of early modern candle- and lamplight might have been approximated experimentally in the gallery or on film. Elsewhere, in the room devoted to ecclesiastical brass kwab, eerie shadows were allowed to emanate from lecterns, chandeliers, and a baptismal arch.

Given these goldsmiths' expert understanding of the light and image effects of their medium, issues of reflection, light, shadow, and degrees of polish and gilding might have been treated in greater depth. Adam van Vianen's sensitivity in these respects was wonderfully demonstrated, however, by a design drawing for an object, perhaps a saltcellar, now attributed to him (fig. 6). 


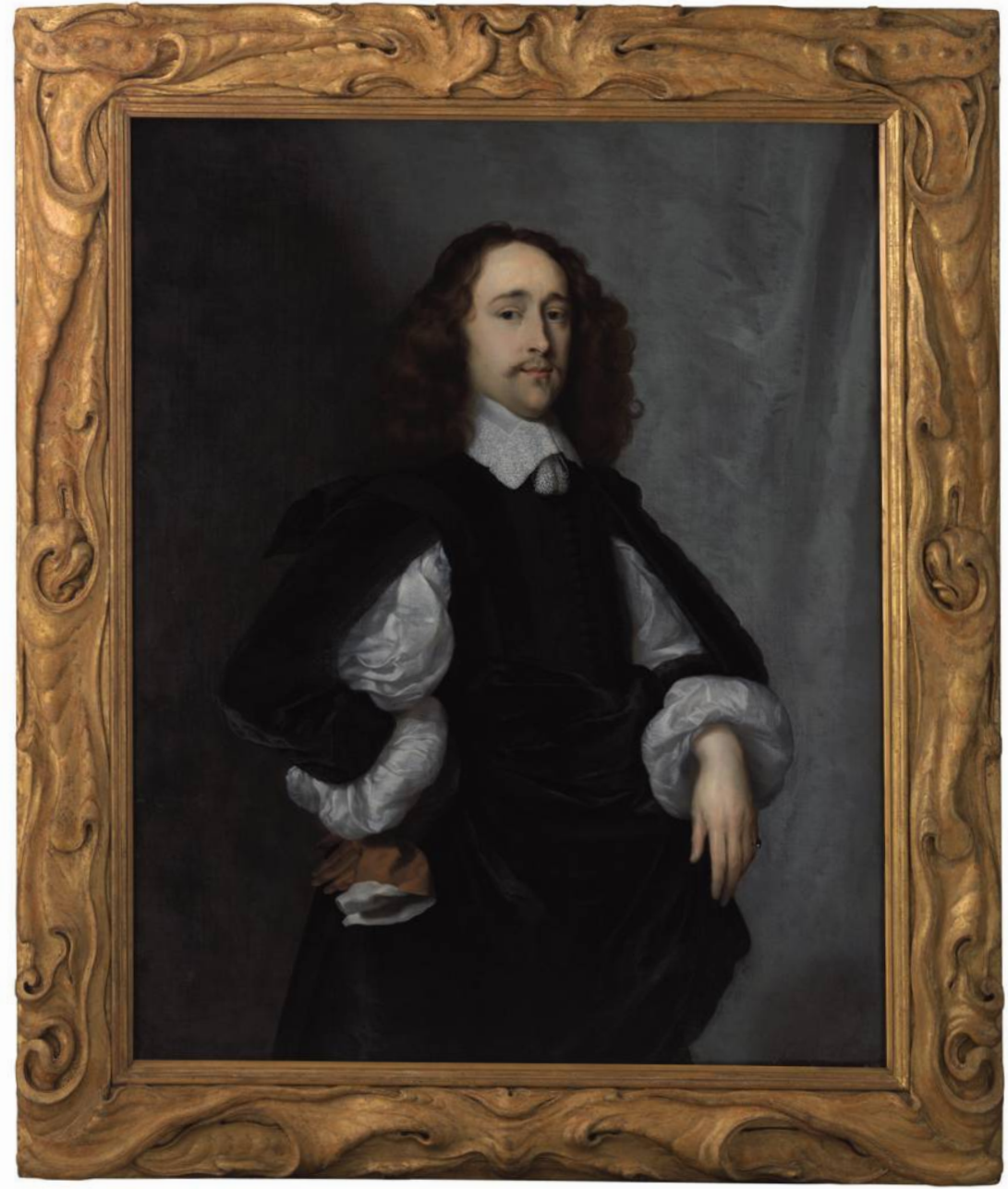

Fig. 7 Cornelis Jonson van Ceulen I, Portrait of Jasper Schade, Utrecht, 1654. Oil on canvas, in the original frame of gilt limewood; $543 / 8 \times 451 \frac{1}{2}$ in. $(138 \times 115.5 \mathrm{~cm})$. Enschede, Rijksmuseum Twenthe, inv. no. 698a. 
Baarsen points out the way in which the drawing indicates "the reflection of light on silver ... its ever-changing effect" (63). While the forms of cherub face and wings ceding into auricular whorls are carefully rendered on the left, the right side slides into dashed horizontal lines that could represent not just light shimmering across the surface but also the indistinct reflection of some unseen future interior. What modern museum photography of precious metalwork has "solved" is the distracting intrusion of such reflections on the metallic surface. The distortion and replication of the viewer's own miniaturized body across lobate forms was a visual phenomenon with which early modern painters, Clara Peeters most notably, played.$^{6}$ In a lobed silver dish by Johannes Pagendarm, an image from the present-my face occluded by an iPhone-fused momentarily with its seventeenth-century surface in a way that connected, formally and physically, my morphing visage to the encircling auricular masks around its edge. In this fusion, impossible to witness in the catalogue's photographs, there was a reminder of the hybrid temporalities_old objects bearing new imagesmade possible by reflective precious metal.

The unresolved glimmering quality of golden and silver auricular ornament found itself particularly suited to the task of framing in the seventeenth century. Carved auricular frames became fashionable farther afield, particularly in England, where portraits by Peter Lely and his contemporaries still sport their original local auricular frames. ${ }^{7}$ Such frames may have domesticated the auricular and become the abiding and eventually unremarkable apparel of family and civic portraits. But auricular ornament still has the ability to subvert the swagger of depicted individuals by suggesting, if not exactly the dissolution of form, then at least a context in which forms remain indistinct. A section of the exhibition was devoted to surviving wooden frames, including those found in the period's elaborate dollhouses and in painted Dutch genre scenes. The best of these frames undulate in irregular layers, like blubber and fish parts that have been cut and piled loosely, then gilded (see fig. 7). Given its short-lived ubiquity, the auricular cartouche would have made a robust thematic to the exhibition and sanctioned some deeper theoretical wrangling about ornament and frame than is attempted here, where the geographical and chronological thrust remains paramount.

$K w a b$ was the rare exhibition that moved the parergon to the center, to become the subject of attention. But this shift in focus raises the question of where, and 


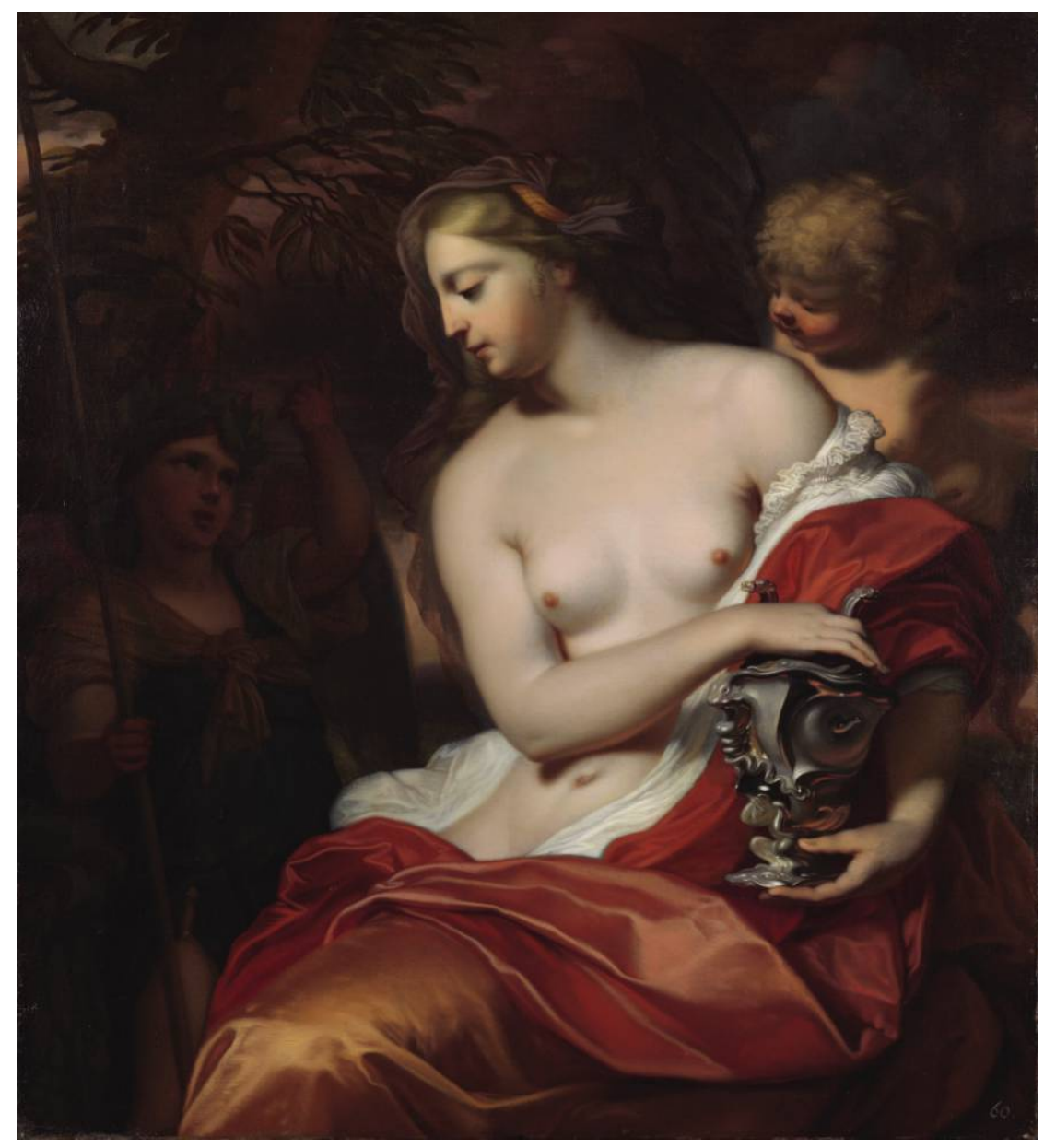

Fig. 8 Barend Graat, Pandora, 1676. Oil on canvas; 441/2 ×401/4 in. $(113 \times 102 \mathrm{~cm})$. Amsterdam, Rijksmuseum, inv. no. SK-A-5027. 
how, meaning can be found in the absence of text and narrative content, a fraught debate that carries over from the field of seventeenth-century Dutch painting. "As ornament is essentially abstract and as the decorative arts have hardly ever been the subject of theoretical writings, an investigation into the significance of the auricular is doomed to remain largely subjective," Baarsen writes, overlooking, or at least declining to engage with, the growing critical literature on ornament (12). ${ }^{9}$ Describing auricular forms as "essentially abstract," moreover, misses something important about this decorative mode. There is enough in the most accomplished auricular pieces that is recognizable from the viewer's own visual experience to elicit the response that is implied but never fully explored here: discomfort, disgust, shrinking away but then needing to look, as if at a terrible wound or a monster, then compensating for that initial shock with laughter and delight. The clear bodily references of auricular vessels hit their unheimlich mark precisely because of their halffamiliarity, whether it is found in the starfish skin deployed in the border of Warnberger's stupendous basin or in the tufts of hair that seem to grow from nowhere in works by the Van Vianens. Baarsen's assertion that "the history of employment of kwab is of little assistance in trying to unravel its meaning" may aim to preempt the "sexual and vanitas interpretations" that have been applied to kwab, most effectively by Antje-Maria von Graevenitz (12, 250n8). ${ }^{10}$ But the appearance of auricular ornament within and beside explicit references to sex, death, and radical transformation suggests that those themes cannot be entirely ruled out, though the exhibition preferred, it seemed, to studiously avoid them. ${ }^{11}$

Barend Graat's Pandora of 1676, for example, depicts a round-limbed female nude, shrugging off pumpkin-colored silk, who holds a modified version of the Amsterdam ewer, the rising snail-head of the lid slid between two fingers (fig. 8). The wall and catalogue texts skirt the implication of this choice-that Van Vianen's slithery ewer, with creaturely forms seeming to wrestle themselves from its surface, made an appropriate vessel for "the box containing all evils"instead commenting on design features: Graat's "suppression" of the object's handle and modification of its lid (194). What seems to be suppressed here, however, is any attempt to associate the tumultuous forces of death and desire with snakerij, or an acknowledgment that paintings themselves might constitute evidence of contemporary interpretation. 


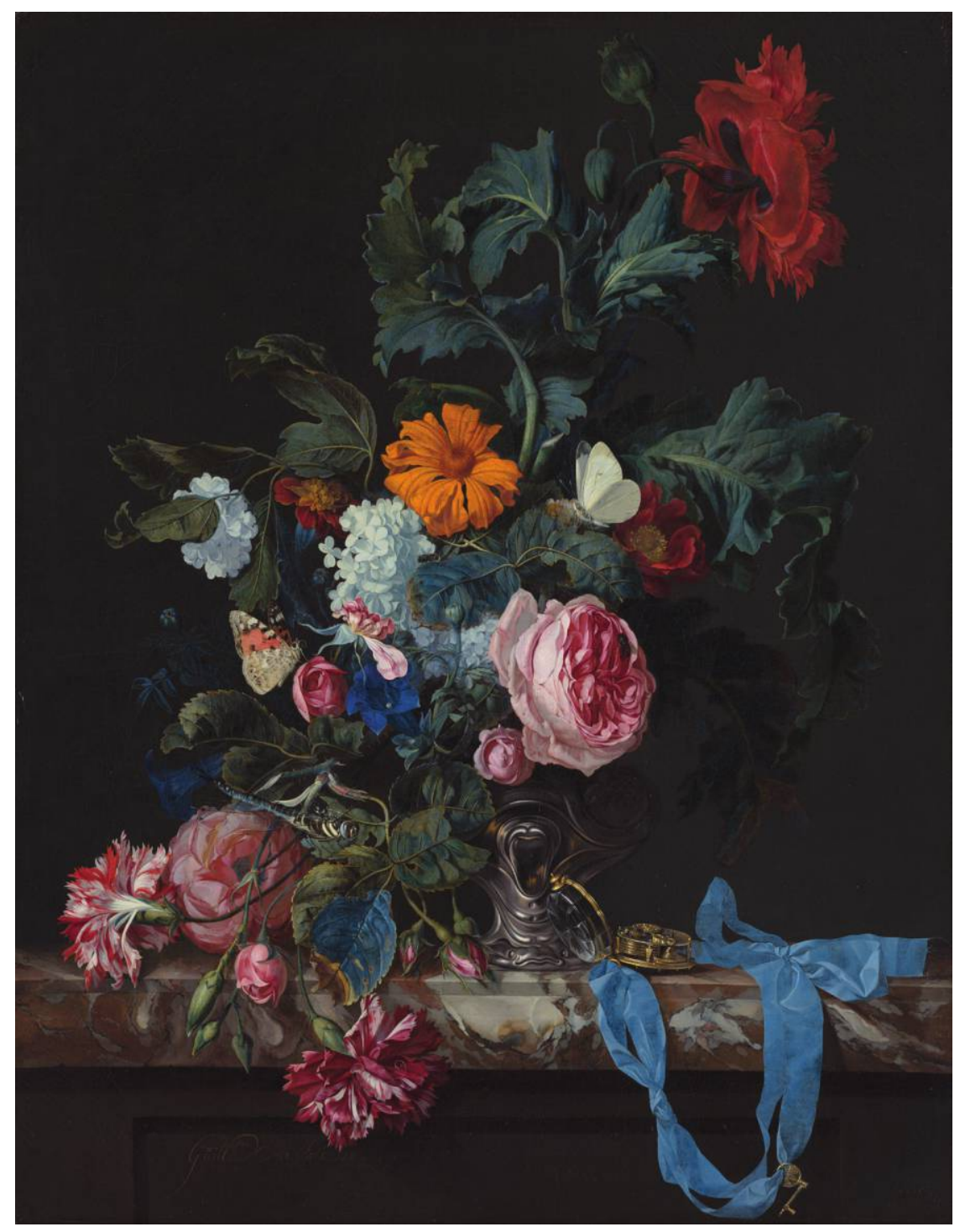

Fig. 9 Willem van Aelst, Flower Still Life with Watch, 1663 . Oil on canvas; $245 / 8 \times 19 \frac{3}{8} \mathrm{in}$. $(62.5 \times 49 \mathrm{~cm})$. The Hague, Mauritshuis, inv. no. 2. 
Writing on a still life by Willem Kalf that depicts an auricular ewer (a painting absent from the Kwab exhibition, despite its permanent home in the Rijksmuseum), Celeste Brusati has recently explored how "still life pictures remake their subjects for particular kinds of visual consideration." ${ }^{12}$ As he did for many of his subjects, Kalf modified the vessel to suit his purposes, ratcheting up its reflective possibilities and transforming it beyond the physical capabilities of an already extraordinary object. Kalf's remaking of the ewer is an interpretive act, one that deserves consideration beyond the scorekeeping of distinctions between portrayed and extant object, a focus that seemed to dominate many of the wall texts in the exhibition.

The auricular vessel depicted in Willem van Aelst's 1663 still life, we were told, "had evidently lost some of its exceptional status" in the decades since its creation, because in this painting a dramatic asymmetrical flower arrangement has been allowed to partially obscure its surface (fig. 9). Giving greater credit to the formal sophistication of Van Aelst's composition, we might instead see that rather than covering up a passé object, the flowers emphasize certain elements of the vessel, specifically its widening, reflective maw and the beady eyes of its base, forms that are rhymed in the miniature face of the dragonfly cruising in from the left. The contemplation of such formal relationships, as between art and nature, is often understood to be the activity that still lifes prompted. ${ }^{13}$ In the catalogue Baarsen suggests this painting might be a comment on the transient fame of celebrated artists like the Van Vianens (194). Could the association of kwab with fleetingness have been even more expansive? In Van Aelst's still life, an elaborate timepiece is set up against the vessel's auricular base, suggesting that it is not just flowers and fame, but material form in general, that is temporary.

Kwab the exhibition ended at around 1670, a reflection of the show's rigorous historical focus, but also of the style's short window of popularity. Other recent surveys of ornament have taken a broader view: the Cooper Hewitt exhibition Rococo: The Continuing Curve, 1730-2008 traced the legacy of rococo ornament into contemporary design. It would have been interesting to see auricular contextualized in the longer durée, including how historicist concerns of the nineteenth century responded to it. The catalogue makes heavy use of an eighteenth-century folio of drawings recording auricular vessels, soon to be the subject of a publication by Rijksmuseum curator Esther 
van der Hoorn, and it seems a shame not to have extended the story of kwab to such later stages of collection, documentation, and analysis. Such an investigation could have included objects like the electrotype of Paulus van Vianen's Diana cup made by Elkington in 1881, which was almost passed off as the gold original (now in the possession of a German noble family) in the exhibition. ${ }^{14}$

There are twenty-first-century European designers whose work participates in thematic veins related to kwab and suggests something of what was compelling about the auricular style to Golden Age consumers, outside the historically specific appeal of the grotesque and of mannerist conceits. Drawing some of those links was the work not of the exhibition itself but of the gift shop that completed the circuit of its galleries, whose contents were selected by Arne Leliveld of the Amsterdam design store Matter of Material. The chosen pieces are souvenir commodities, to be sure, yet likewise worthy of inclusion in the holdings of a design collection. Some comment wittily on the allure of gold and the molten potential of metal, or provide the means for distortion, like the "window drops"-rubbery, transparent appliques that morph a window view with watery effect-by Arnout Visser and Bas van Tol of the eminent postmodern Dutch design firm Droog. The Push Bowl by Gunnar Rönsch and Stephen K. Molloy (Fundamental Berlin) - a flat lasercut sheet that can stretch three-dimensionally-offers a mechanical means of producing a continually transforming vessel. Loris Jaccard's and Livia Lauber's Tipsy Glasses are common Duralex cups that have been allowed to go wobbly in the heat of a furnace until they slump and tilt like individual characters; the mouthblown forms of Maria Blaisse's Lazy Love Glasses likewise take up the bodily references vessels inevitably inhabit as they swoon, lazily or intoxicatedly, toward each other. All these designs appear alive to the playful and destabilizing erotics of meltable materials and vessel forms that so characterize auricular designs, particularly in silver.

While this collection of contemporary objects might not be the explicitly causal legacy of the auricular, it allows, perhaps, a path to articulating by way of analogy what made, and continues to make, kwab so deliciously strange. If the 2018 exhibition did not dare to make such interpretive leaps, it offered the fertile and expertly prepared ground out of which the next generation of scholarship will grow, a vital achievement. Baarsen's catalogue is, moreover, a tremendous 
resource for scholars of design history and the decorative arts, and a real pleasure for anyone who, like so many artists and kunstkenners over the centuries, has encountered Van Vianen's ewer with amazement and delight and simply wanted more.

\section{-Allison Stielau}

Allison Stielau is lecturer in early modern art at University College London. Her current book project concerns the meltdown and transformation of precious metalwork in the early modern world.

\section{Notes}

1 Sarah D. Coffin and Gail S. Davidson, Rococo: The Continuing Curve, 1730-2008 (New York: Cooper Hewitt Museum, 2008); Michael Snodin and Nigel Llewellyn, eds., Baroque 1620-1800: Style in the Age of Magnificence (London: V\&A Publishing, 2009).

2 The representation of such paintings in the exhibition was admittedly meager; the trompe l'oeil auricular frame on a Holy Family from Kassel was entirely illegible, leading one to question its inclusion.

3 Curators at the Victoria and Albert Museum recently re-created the basin's original purpose as a receptacle for washing the hands in rosewater during banquets, capturing in a short film the effect of water flowing over the basin's own watery silver surfaces. Tessa Murdoch, "A Silver Basin Worthy of Charles I," V\&A Blog, December 7, 2018, https://www.vam.ac.uk/blog/caring-for-our-collections/a -silver-basin-worthy-of-charles-i.

4 For an overview that covers this breadth, see, for example, Johan ter Molen, "Auriculaire," in L'art décoratif en Europe: Classique et baroque, ed. Alain Gruber (Paris: Citadelles \& Mazenod, 1992), 26-91.

5 The black-and-white theme carries insistently into the catalogue, designed by Irma Boom and Eva van Bemmelen, where the melting typeface of the chapter titles, reminiscent of a lava lamp, evokes 1960s grooviness more immediately than the formal ambiguity of kwab.

6 Celeste Brusati, "Stilled Lives: Self-Portraiture and Self-Reflection in Seventeenth-Century Netherlandish Still Life Painting," Simiolus 20, no. 2/3 (1990-91): 168-82.

7 A major international conference on auricular frames, bringing together conservators, curators, and other specialists, was organized by Gerry Alabone and Lynn Roberts at the Wallace Collection in October 2016. For published abstracts and papers, along with a summary, see "Archives," Auricular Style: Frames, accessed March 14, 2019, https://auricularstyleframes.wordpress.com/.

8 For a cogent overview of debates on meaning and interpretive method in this field, see Mariët Westermann, "After Iconography and Iconoclasm: Current Research in Netherlandish Art, 1566-1700," Art Bulletin 84, no. 2 (2002): 351-72.

9 As just one in a host of recent texts, I cite Gülru Necipoğlu and Alina Payne, eds., Histories of Ornament: From Global to Local (Princeton, NJ: Princeton University Press, 2016).

10 Antje-Maria von Graeventiz, Das niederländische Ohrmuschel-Ornament: Phänomen und Entwicklung dargestellt an den Werken und Entwürfen der Goldschmiedefamilien Van Vianen und Lutma (Bamberg: Rudolph Rodenbusch, 1973). 
11 No mention was made in the exhibition itself, for example, that the position of the two lizards inside Adam van Vianen's ewer is explicitly sexual: “[T] he male bites the female in her back to prepare her for mating" (50). The interior of the ewer can be seen in Robert Erdmann's film, now viewable online: https://www.youtube.com/watch?time_continue=5\&v=NgbSfz5VP10, acessed April 9, 2019.

12 Willem Kalf, Still Life with a Silver Jug and Porcelain Bowl (ca. 1655-60), Rijksmuseum inv. no. SK-A199. Celeste Brusati, “Willem Kalf on Reflexykonst: The Aesthetics of Transformation in Still Life," in Art as Worldmaking: Critical Essays on Realism and Naturalism, ed. Malcolm Baker and Andrew Hemingway (Manchester, UK: Manchester University Press, 2018), 147-64, at 150.

13 Lawrence O. Goedde, “A Little World Made Cunningly: Dutch Still Life and Ekphrasis,” in Still Lifes of the Golden Age: Northern European Paintings from the Heinz Family Collection, ed. Ingvar Bergström (Washington, DC: National Gallery of Art, 1989), 34-44.

14 The label referred to the Elkington copy simply as "this gold cup" and did not explain what an electrotype is. 